\title{
Soviet Legal and Criminological Debates on the Decriminalization of Homosexuality (1965-75)
}

\author{
Rustam Alexander
}

Those few historians who have attempted to write the history of Soviet sexuality concur that from the 1930s through the Soviet collapse, Soviet society, and especially the Soviet state, were deeply hostile to anything that deviated from "traditional" sex in the bedroom. ${ }^{1}$ Sex was generally deemed a topic unfit for public discussion and any deviations from "normal" sexuality were condemned and criminalized by Soviet law. ${ }^{2}$ And yet, despite these long-standing and institutionalized prudish attitudes towards sex and hostility towards homosexuality, during the late Soviet period, a group of legal scholars spoke out in favor of decriminalizing consensual sodomy. This is in sharp contrast to the conventional view of the Brezhnev period as a time of stagnation and sexual conservatism, and offers a window onto a very different dimension of that period-and yet we know very little about it. The fact that these debates took place has been noted by pioneering scholars of Soviet sexuality such as Igor Kon and, more recently, Dan Healey, yet neither has discussed them in much detail. ${ }^{3}$

In this article, I conduct a discourse analysis of the manuals, textbooks, and dissertations on sex crimes and on the law on sodomy, produced by Soviet experts in crime and law in the period from 1960 to 1975. I focus particularly on the debates over whether the part of the law that criminalized consensual sex between two men should be retained. Archival sources, such as transcripts of the proceedings of legislative commissions in the Russian Socialist Federated Socialist Republic (RSFSR) and the Latvian SSR, which included discussions of sodomy laws in these republics, are also employed in the article. ${ }^{4}$

My analysis of these sources reveals that while all the participants in the discussions on the sodomy statute were scholars involved in the study of law and crime, there was a clear distinction in their position. On the one side stood scholars, who were legal experts by training and who worked in relatively "liberal"

This article is part of my research project that I am currently completing in the School of Historical Studies at the University of Melbourne, which is supervised by Dr. Julie Fedor, to whom I am grateful for invaluable comments on earlier versions of this article. I am also grateful to two anonymous readers who greatly assisted in improving my article. Finally, I am indebted to my friend Peter McKerrow, who provided me with thoughtful comments on the intricacy of translation of Russian legal terms into English. All the deficiencies in this work are mine only.

1. See for example: Igor Kon, The Sexual Revolution in Russia: from the Age of the Czars to Today (New York, 1995), 85; Anna Rotkirch, “'What Kind of Sex Can You Talk about?': Acquiring Sexual Knowledge in Three Soviet Generations,” in Daniel Bertaux, Paul Thompson, and Anna Rotkirch, eds., Living through the Soviet System (New Brunswick, 2005), 93-199.

2. Kon, Sexual Revolution, 85. See also: Rotkirch, "What Kind of Sex?," 93-199. On the criminalization of homosexuality see: Dan Healey, Homosexual Desire in Revolutionary Russia: The Regulation of Sexual and Gender Dissent (Chicago, 2001).

3. Kon, Sexual Revolution, 244. Healey, Homosexual Desire, 247-48.

4. These sources were obtained during my fieldwork in Russia and Latvia in September 2016. They were gathered from the Russian State Library, the State Archive of the Russian Federation, and the State Archive of Latvia. 
university environments-for clarity, I will refer to this group as "civilian" scholars. ${ }^{5}$ These scholars argued for the decriminalization of consensual sodomy. On the other side were Interior Ministry (henceforth, MVD, from the Russian initials) scholars, who were affiliated in one way or another with the MVD and who were consistently opposed to the decriminalization of consensual sodomy. ${ }^{6}$ This article will demonstrate that the positions of the two camps regarding the retention of the anti-sodomy statute were moving in different directions throughout the period in question: civilian scholars' views were becoming more liberal, while the views of MVD scholars were growing more conservative.

The examination of the debates over the criminal status of homosexuality, which started in the late 1950s and continued up to the demise of the Soviet Union adds depth and nuance to our scant knowledge of the history of homosexuality during the Brezhnev era and contributes to our understanding of the interplay between the broader European movement towards decriminalization of sodomy and related debates in the Soviet Union. It also seeks to fathom why such debates had resulted in decriminalization of homosexual activity elsewhere in the communist bloc but not in the Soviet Union. Finally, it lends fresh insight into the events that preceded the Russian Federation's eventual decriminalization of sodomy in 1993, demonstrating that calls for decriminalization had in fact been present for decades in Soviet juridical discourse.

The article begins by looking at the brief discussions of the law on sodomy that took place in the late 1950s in the RSFSR and in the early 1960s in the Latvian SSR during the drafting of new criminal codes in these republics. ${ }^{7}$ It then turns to examine the discussion between civilian and MVD scholars of the criminal status of homosexuality in the USSR in the period from 1965 to 1975 . The article concludes by reflecting on the implications of the discussion and the possible reasons why it did not result in the decriminalization of consensual sodomy in the Soviet period.

\section{The Soviet Anti-Sodomy Law and Khrushchev's De-Stalinization}

The anti-sodomy law, Article 154a of the USSR Criminal Code, was approved under Iosif Stalin in $1934 .{ }^{8}$ The article consisted of two parts-the first (154a-I)

5. For the purposes of clarity, I refer to this group as "civilian" scholars, in order to differentiate them from the scholars affiliated with the state's law-enforcement and security agencies, that is, the MVD scholars. It should be noted, however, that there was considerable overlap across these two categories. Some scholars maintained professional ties with the MVD educational institutions, for example, teaching there, while their principal scientific activities lay within "civilian" universities.

6. Ministerstvo Vnutrennikh Del-the Ministry of Internal Affairs. Again, I use the term "affiliated" here for the sake of brevity, as shorthand for what was often a more complex relationship between these scholars and the MVD. By "affiliated" or "MVD scholars," I mean scholars who held positions at the MVD Higher School and/or were commissioned by the MVD to produce manuals for criminal investigators.

7. I obtained these files during my fieldwork in Russia and Latvia in autumn 2016. I was unable to find similar files in the state archives of Ukraine, Belarus, Lithuania and Estonia, which I also consulted in the course of this research trip. I am grateful to Ineta Lipša for alerting me to the existence of the Latvian document in the State Archive of Latvia.

8. Healey, Homosexual Desire, 185. 
criminalized consensual sodomy (punishable by deprivation of liberty for a term of three to five years), while the second part (154a-II) criminalized socalled "forcible" sodomy (with a more severe penalty of five to eight years). ${ }^{9}$

The few historical accounts of the adoption of this law point out that no announcement was made explaining the rationale for its introduction. The existing sources are too scant to deduce with certainty why the Stalinist leadership chose to do so. ${ }^{10}$ Historians have made some attempts to investigate this question. Dan Healey and Laura Engelstein agree that political reasons were an important factor and link the adoption of the law to the Stalinist leadership's drive to tighten control over the Soviet people's intimate lives and to deter political disloyalty, which the Stalinist leadership associated with homosexuality. ${ }^{11}$ Dan Healey also suggests that anxieties about the declining birthrate were relevant. ${ }^{12}$

In 1956, three years after Stalin's death, Nikita Khrushchev launched his de-Stalinization campaign, highlighting the necessity to restore "socialist legality." The terror of the Stalin era was now curbed and as part of this process, scholars and officials were encouraged to contribute to the liberalization of Soviet criminal law. ${ }^{13}$ The study of criminology, which had been effectively proscribed under Stalin, was now gradually reviving, allowing for fresh criminological empirical research to emerge within the MVD as early as $1955 . .^{14}$ This period also witnessed the preparation of new republic criminal codes, as legislative commissions including top Soviet specialists in crime and law were set up and entrusted with the task of reviewing the Stalin-era laws to decide which should remain in force. ${ }^{15}$ As we shall see, the law on sodomy was also discussed at the meetings of these commissions; in fact, it seems that there were attempts to moderate the penalty for consensual sodomy by reducing the maximum sentence prescribed by Article 154a-I from five years to three years. Most importantly, at this time there was a possibility that the article criminalizing consensual homosexual acts between men could have been abolished at least in the RSFSR.

References to possible liberalization of the law first appear in the minutes of a meeting of a subcommittee of the RSFSR Legislative Commission held

9. Mark I. Iakubovich and Vladimir F. Kirichenko, Sovetskoe ugolovnoe pravo (Moscow, 1958), 342.

10. Healey, Homosexual Desire, 186.

11. Ibid., 221. See also: Laura Engelstein, "Soviet Policy toward Male Homosexuality: Its Origins and Historical Roots," in Gert Hekma, Harry Oosterhuis, and James D. Steakley, eds., Gay Men and the Sexual History of the Political Left (New York, 1995), 169-70.

12. Healey, Homosexual Desire, 202-3. The linkage between homosexuality and political disloyalty is not peculiar to the Soviet Union; see for example: David K. Johnson, The Lavender Scare: The Cold War Persecution of Gays and Lesbians in the Federal Government (Chicago, 2004).

13. Peter H. Juviler, "Criminal Law and Social Control” in. Donald D. Barry, William E. Butler, and George Ginsburgs, eds., Contemporary Soviet Law: Essays in Honor of John N. Hazard (The Hague, 1974), 21.

14. Peter H. Solomon Jr., Soviet Criminologists and Criminal Policy: Specialists in Policy-Making (New York, 1978), 53.

15. GARF, f. A-385, op. 26, delo 152, 1.292-94 (Materialy po proektu Ugolovnogo kodeksa RSFSR /stenogrammy plenarnykh zasedanii Komissii zakonodatel'nykh predpolozhenii). 
on July 23, 1959. This subcommittee was comprised of seven distinguished legal experts and scholars, and was chaired by Boris Sergeevich Nikiforov. ${ }^{16}$ As a recommendatory body responsible for proposing changes to the law, the subcommittee put forward a list of reforms of the existing Stalin-era laws, including the law on sodomy. ${ }^{17}$ The new version of the law, proposed by Nikiforov's commission read as follows:

Article 100.

In the first part of article 100 to introduce sanction [ustanovit' sanktsiiu]deprivation of liberty for the term of up to three years or exile for the same term.

For the second part of article 100 the draft as formulated is as follows:

"Sodomy committed with means of violence or in relation to a minor or with the use of dependent position, is punishable by deprivation of liberty for the term from three to eight years with exile or without". ${ }^{18}$

This new version of the law would have reduced the maximum sentence for consensual sodomy from three to five years with no minimum sentence. The proposed amendment to the second article of the law, which penalized aggravated sodomy, would have retained the maximum sentence of eight years but reduced the minimum from five to three years.

One month later, on August 27, 1959 a Commission of Legislative Propositions [Komissiia zakonodatel'nykh predpolozhenii], consisting of fourteen distinguished legal experts and criminologists of the RSFSR, and chaired by Professor of Jurisprudence Aleksei Gertsenzon, gathered to approve the draft prepared by the Nikiforov commission. ${ }^{19}$ The archival transcript of this discussion reveals that at this stage a proposal emerged to abolish the law on consensual sodomy altogether, despite the reduced maximum sentence for consensual sodomy already proposed by Nikiforov's commission:

GERTSENZON- ... Article 100-sodomy.

Any suggestions regarding the first part [on voluntary sodomy]?

16. Among other participants were: P.A. Astakhov, Z.A. Vyshinskaia, A.A. Plankin, T.L. Sergeeva, V.I. Kurliandskii, and M.F. Orlov.

17. GARF, f. A-385, op. 26, delo 153, 1. 182-83 (Stenogramma zasedaniia podkomissii tov. B.S. Nikiforova po rassmotreniu glav III, IV, XI proekta Ugolovnogo Kodeksa RSFSR).

18. Apparently, the reference number of the article changed from " $154-\mathrm{a}$ " to " 100 " due to the removal of unneeded articles and inclusion of the new ones. GARF, f. A-385, op. 26, delo 153, 1. 183.

19. Aleksei Adol'fovich Gertsenzon was a Professor of Juridical Science. From 1931, he was Professor in the Institute of Soviet Law. Throughout his career, he wrote more than 250 research papers and publications on the theory of criminal law and history of criminal sociology. From 1963 and until his death he directed the All-Union Institute for the Study of the Causes and Elaboration of Measures for Preventing Crime, founded in the same year. See the entry for Aleksei Adol' fovich Gertsenzon (1902-1970), Vidnye uchenye iuristy Rossii (Moscow, 2006), 98. Among other participants, the following persons (without initials) were listed: Astakhov, Avdeev, Gertsenzon, Grishaev, Durmanov, Kopylovskaia, Korotkov, Mikhailov, Nikiforov, Poretskaia, Stepichev, Starikov, Urakov, Orlov. 
NIKIFOROV-The first part of the law is totally incomprehensible.

STEPICHEV-The first part can be abolished.

GERTSENZON-There are suggestions to abolish the first part. I am opening this up to a vote. Does anyone support the abolition of the first part?

KOROTKOV-We can't abolish this norm. On what grounds do you want to do that?

GERTSENZON-Are we going to open up a discussion or not? Who is in favor of opening discussion of the article? (2). ${ }^{20}$ We are not going to discuss it then. The article stays, then. What are the suggestions regarding the essence of the Article? Here the punishment [repressiia] is to be reduced compared to the previous penalty. Deprivation of liberty for up to three years or exile for up to three years. So, comrades, are we approving the first part of the Article? We're approving it.

The second part: Any suggestions? No.

The whole article is approved..$^{21}$

The brevity of the minutes leaves the participants' motives largely opaque and it is difficult to say whether other members, apart from Nikiforov and Stepichev who expressed support for decriminalization, were of similar opinion, since almost none of them had previously spoken out on this issue. Nikiforov's role as chair of the subcommittee that proposed reducing the severity of the law and his comment that the law was "totally incomprehensible" would appear to indicate that he was a strong proponent of abolishing the law entirely.

Judging by the reticence of other participants in the discussion on the sodomy law, compared to their extensive contributions on other articles of the Criminal Code, we might speculate that most of the scholars present found discussing the subject in detail quite uncomfortable. As legal experts they would most likely have been inadequately prepared to objectively examine the issue. As Igor Kon has noted, the "suppression of sexual culture" and absence of "adequate understanding of sexuality in the public consciousness," peculiar to the Stalin era and certainly still prevalent during the early years of Khrushchev's rule would have inhibited open discussion.22

Interestingly, despite Gertsenzon's commission approving Nikiforov's recommended version of the sodomy law, which reduced sentences for both consensual and aggravated sodomy, the proposed changes never became law. The archival sources are silent on the fate of the proposed reforms, which may either have been further reviewed and rejected or quashed by the intervention of a higher-level authority. Yet, the final version of the law, adopted by the Supreme Soviet of the RSFSR in 1960, differed from the version first proposed

20. Apparently, this number refers to the votes in favor of continued discussion of the law. Presumably, the two people voting in favor were Stepichev and Nikiforov.

21. GARF, A-385, op. 26, delo 152, 1. 292-93 (Stenogramma zasedaniia Komissii po rassmotreniiu proekta UK RSFSR. 27 August 1959).

22. Kon, Sexual Revolution, 85. 
by Nikiforov's commission and later approved by Gertsenzon's commission. It read:

Article 121. Sodomy

Sexual intercourse between a male and a male (sodomy) is punishable by deprivation of freedom for a term of up to five years.

Sodomy committed with the use of physical violence, threats, or in relation to a minor, or with the use of the dependent position of the victim is punishable by deprivation of freedom for a term of up to eight years. ${ }^{23}$

While minimum sentences both for consensual and aggravated sodomy were eliminated altogether, the maximum penalty for consensual sodomy was increased from three years (as the version approved by Gertsenzon commission had proposed) to five years.

\section{The Latvian Case: Attempts to Criminalize Lesbian Sexual Activity}

New sources suggest that the process of revising the sodomy laws of the Stalinist Criminal Code in each of the Soviet republics varied. For instance, in Latvia, discussions about revising the legal treatment of homosexuality had a very different focus. On March 24, 1960, during the drafting of the Criminal Code of the Latvian SSR, the head of the Latvian SSR's law commission considered a proposal from the Riga city directorate of the militia to extend the legal definition of sodomy and to criminalize female same-sex relations. The proposal noted that, "in practice one may encounter cases of satisfaction of sexual desire between the persons of the same sex, which do not fall under the definition of 'sodomy,' yet these activities also pose a danger to society." 24

The commission reconvened on October 14, 1960, but the minutes of this meeting make no reference to the militia's proposal. The minutes record that Fridrikson, the chair of the meeting, noted that all the proposals presented to the commission's meeting in March had been sent to Moscow for review. Fridrikison reported: "As you remember, in March we discussed the Criminal Code draft, which was subsequently discussed by academics in Moscow at a meeting in the Juridical Department of the Presidium of the Supreme Soviet of the USSR." ${ }^{25} \mathrm{He}$ also acknowledged the significance of the RSFSR reviseddraft Criminal Code as a template for revising the LSSR's Criminal Code: "In our work we were essentially using the RSFSR Code; we were borrowing from the RSFSR draft, which has been approved everywhere."26 It therefore seems probable that the proposals to criminalize lesbianism were rejected, perhaps by the authorities in Moscow.

23. Boris S. Nikiforov, Nauchno-prakticheskii kommentarii Ugolovnogo kodeksa RSFSR (Moscow, 1964), 281.

24. The State Archive of Latvia, f. 938, op. 6, delo 66, 1. 82 (Proekt Ugolovnogo kodeksa i zamechaniia po proektu).

25. The State Archive of Latvia, f. 938, op. 6, delo 64, 1.1 (Stenogramma soveshchaniia po obsuzhdeniu proekta Ugolovnogo kodeksa LSSR).

26. Ibid., 71. 
The Latvian militia's proposal to criminalize same-sex relations between women represented a significant shift from the existing Stalin-era sodomy statute, which did not criminalize female homosexual acts. ${ }^{27}$ Interestingly, the moves to liberalize the law in the early years of Khrushchev's rule seem to have had a paradoxical effect on the discussion of lesbianism: although lesbianism became the subject of specialist discussion for the first time since Stalin's death, at no point did the liberalizing tendencies of Khrushchev's era encourage or lead to acceptance or tolerance of female homosexuality.

On the contrary, the first years of Khrushchev's rule saw a number of proposals to criminalize female same-sex relations. Advocates of such measures could be found in the ranks of Soviet law-enforcement agencies, the GULAG camp directors and the GULAG camp doctors. Dan Healey tells us that proposals to proscribe female same-sex relations came from the GULAG directors as early as $1956 .{ }^{28}$ As new evidence shows, support for these proposals continued through the late 1950s. In 1958 the head of the Siberian GULAG, I. M. Velikanov, concerned about the increasing incidence of sexual relations between women in the Siberian GULAG, petitioned the Presidium of the Supreme Soviet of the USSR with a proposal to impose a criminal penalty for lesbianism..$^{29}$ Such propositions were the result of a curious amalgam of Khrushchev-era liberalization and Stalin-era attitudes toward sexuality still fresh in people's minds. Velikanov's proposal and similar calls to criminalize female same-sex relations were never taken up, however.

In his recent work, Dan Healey identified that Soviet authorities preferred to deal with lesbianism in a medical context, rather than through the criminal law. ${ }^{30} \mathrm{He}$ also noted in his previous work that although female homosexuality was not criminalized by Stalin, the motherhood cult was an important reminder of the purpose of women's sexuality and thus a deterrent from sexually deviant practices. ${ }^{31}$ The motherhood cult persisted during the Khrushchev period. The sex education campaign launched under Khrushchev constantly reminded women about their role as mothers, and doctors who attempted to "treat" lesbianism (primarily in the GULAG) seemed to believe that female homosexuality could be "cured" if a woman succumbed to the instinct of motherhood. ${ }^{32}$ For instance, one psychiatrist in the GULAG observed that upon becoming mothers, lesbians tended to forget about their experience of same-sex relations: "It is interesting that pregnancy and child-bearing, evoking the woman's biologically-inherent aspiration to become a mother,

27. For a discussion on why female same-sex relations were not prohibited see: Healey, Homosexual Desire, 196-202.

28. Dan Healey, "From Stalinist Pariahs to Subjects of 'Managed Democracy': Queers in Moscow 1945 to the Present" in Matt Cook and Jennifer V. Evans, eds., Queer Cities, Queer Cultures: Europe since 1945 (London, 2014), 99.

29. GARF, P.-9414, op. 1, delo 2882, 1. 144 (Nachal'niku GULAGa MVD SSSR). I was first alerted to the existence of this document by Dan Healey's work, "From Stalinist Pariahs."

30. Ibid., 99.

31. Healey, Homosexual Desire, 204.

32. Deborah A. Field, Private Life and Communist Morality in Khrushchev's Russia (New York, 2007), 51-65. 
even after lasting perverted forms of co-habitation with women before pregnancy, decisively eliminate these abnormal forms of sexual relations." 33

The transcripts of the discussions on the sodomy law carried out by Russian and Latvian legislative commissions in the latter half of the 1950s illustrate the emergence of two distinct strands of thought about the law. On the one hand, an argument for its decriminalization was proposed by "civilian" legal experts and on the other, calls for its expansion were issued by law-enforcement agencies. These two conflicting approaches to the law would also be reflected in the renewed discussion of the law that followed several years later.

\section{The Legal Argument for Decriminalization}

Discussion between civilian and MVD scholars about the anti-sodomy law continued after Khrushchev's removal from power and it unfolded against the backdrop of the gradual revival of professional and academic expertise in Soviet criminology, a field of social science effectively proscribed under Stalin. ${ }^{34}$ As this expertise revived and developed under Khrushchev, so did the range of activities in which Soviet legal and law-enforcement experts were involved. These included efforts to improve criminological expertise within the MVD on how to handle the investigations of sexual crimes. MVD officers were often completely unskilled in the investigation of these crimes and lacked much-needed training and expertise. ${ }^{35}$ In response to these deficiencies, the MVD commissioned several scholars to write training manuals for criminal investigators and for its schools. It was in one such manual that the first scholarly examination of the anti-sodomy statute was undertaken.

The manual titled Investigation of Sex Crimes and published in 1965 by criminologist Mikhail Nikitovich Khlyntsov of the Saratov Legal University was specifically intended for students and lecturers of the MVD schools. The author of the manual depicted the dangers of sodomy in these terms: "The extreme danger of this crime lies in its encroachment on the moral foundations of society and its demoralizing influence on the psyche of society members.... The victim of this crime is the prevailing mode of sexual relations in our country, which the law seeks to safeguard. .."36

Khlyntsov's interpretation of the utility of the law on sodomy was consistent with the Soviet public discourse on sex and sexual morality, first widely promulgated by the Khrushchev regime and further promoted under Leonid Brezhnev. As Deborah Field has shown, the focal point of this discourse was

33. GARF, f. P-9414, op.1, delo 2896, 1. 193 (V. S. Krasuskii, K voprosu izucheniia izvrashchennykh form polovykh vzaimootnoshenii zakliuchennykh zhenshchin).

34. Peter H. Solomon, "Soviet Criminology: Its Demise and Rebirth, 1928-1963," in Roger Hood, ed., Crime, Criminology and Public Policy: Essays in Honor of Sir Leon Radzinowicz (London, 1974), 571-95. See also: Louise Shelley, "Soviet Criminology: Its Birth and Demise, 1917-1936 (PhD diss., University of Pennsylvania, 1977); and Sharon A. Kowalsky, Deviant Women: Female Crime and Criminology in Revolutionary Russia, 1880-1930 (DeKalb, 2009), 187-92."

35. Mikhail N. Khlyntsov, Rassledovanie polovykh prestuplenii (Saratov, 1965), 4.

36. Ibid., 141. 
the necessity to prevent Soviet children and adolescents from engaging in sexually immoral behavior, including casual sexual relations, pre-marital sex, and promiscuity. ${ }^{37}$ The existence of the anti-sodomy statute, according to Khlyntsov's manual, was justified because it upheld communist morality and the very "moral foundations" of Soviet society. ${ }^{38}$ The desire of a homosexual to engage in sodomy was presented simply as a result of "depravity" (razvrashchennost'): "The propensity for sodomy in certain individuals can be explained by ... their lack of fulfilment with normal means of satisfying sexual desire and the pursuit of new sensations, which attests to their debauchery [razvrashchennost'] and their contempt for moral norms." 39

However, not all scholars specializing in crime and law espoused similar views. During the 1960s, new attitudes to the law on consensual sodomy were also emerging. These did not view consensual sodomy as simply a product of "moral perversion." These viewpoints were advanced by Soviet "civilian" legal experts, who were under less pressure to square their views with the practical demands of the MVD. They worked in regular educational institutions and their work was not commissioned or controlled by the MVD. These legal experts were members of the Soviet intellectual community, who had developed their criticisms of the consensual sodomy law during the Khrushchev thaw and began to cautiously articulate them under Brezhnev.

Aleksei Nikolaevich Ignatov was one such scholar whose pragmatic approach to the law on sodomy was reflected in his manual Liability for Crimes against Morality (1966). ${ }^{40}$ Ignatov held a $\mathrm{PhD}$ in jurisprudence from Moscow State University. He had taught criminal law at various universities in Moscow since $1953 . .^{41}$ Although he did not suggest in his manual that the law on consensual sodomy be abolished, Ignatov did argue that not all homosexual liaisons between men should be criminalized under the existing legislation. He contended that since Soviet law only criminalized sodomy (or "pederasty" [pederastiia], which referred to anal intercourse between two men), then other sexual activities between two men should not be deemed illegal. Ignatov directly criticized Soviet judicial decisions on this issue, in a statement that is surprisingly frank: "We cannot approve of the tendency of some courts to expand the notion of sodomy, placing any satisfaction of sexual desire between men within this category. If two men commit consensual depraved acts between one another [without engaging in anal intercourse], thereby satisfying their sexual desire, they should not be subjected to a criminal penalty, since such actions are not perceived by the Soviet criminal code as a crime." ${ }^{2}$

37. Deborah A. Field, "Communist Morality and Meanings of Private Life in Post-Stalinist Russia, 1953-1964” (PhD diss., University of Michigan, 1996), 116.

38. Khlyntsov, Rassledovanie polovykh prestuplenii, 141.

39. Ibid., 145.

40. Aleksei N. Ignatov, Otvetstvennost' za prestupleniia protiv nravstvennosti: Polovye prestupleniia (Moscow, 1966).

41. Entry for Aleksei Nikolaevich Ignatov (1902-1970), Vidnye uchenye-iuristy Rossii: Vtoraia polovina XX veka (Moscow, 2006).

42. Ignatov, Otvetstvennost' za prestupleniia, 180. 
Ignatov had essentially identified a legal loophole: in theory, homosexual men were allowed to engage in any other form of sexual activity, other than anal intercourse, since the latter was the only practice to be criminalized by law. However, as this passage suggests, this fact tended to be overlooked sometimes by judges, and homosexual men were frequently brought before court even for technically legal activities. We know that this was the case under Stalin: Dan Healey tells us about a sodomy trial in 1939, in which the advocate of a defendant accused of sodomy argued that his client may have committed depraved acts, but that these did not constitute sodomy and hence were not illegal. In this case, however, the court rejected this argument, asserting that the act of sodomy had nevertheless taken place (but without specifying how sodomy was defined here). ${ }^{43}$ Apparently, such incorrect enforcement of the law on sodomy was continuing under Khrushchev; Ignatov was the first legal expert to appeal publicly that its enforcement be brought in line with the law.

Unlike Khlyntsov, who asserted that homosexuality was a result of "depravity," Ignatov encouraged his readers not to jump to conclusions, and to consider whether other factors could contribute to the development of homosexuality. In doing so, he presented his readers with arguments derived from the pre-revolutionary Russian forensic and medical literature, which suggested that congenital factors could be responsible for homosexuality. ${ }^{44}$ Ignatov suggested that the nature of homosexuality should be explored further in order to ascertain whether it was indeed a "pathological phenomenon"; if so, the existing criminal law penalizing it should be reviewed accordingly. He argued: "The examination of homosexuality's nature will help to establish the extent to which it ought to be punishable and to facilitate the correct application of criminal law to it, especially given that the inexpedience of criminal punishment for consensual homosexuality has been repeatedly expressed in the literature." ${ }^{5}$ Thus, instead of solely relying on "communist morality" in his approach to homosexuality, as scholars like Khlyntsov had done, Ignatov preferred to ground his arguments in science, reaching back to the pre-revolutionary period to do so.

Ignatov's tentative suggestion that homosexuality could be a matter of therapeutic, rather than police concern, coincided with the emergence of Soviet sexology or "sexopathology" (seksopatologiia) in the early 1960s, which focused on sexual health issues, including "sexual perversions." 46 This development came late, compared to some countries in eastern Europe, where sophisticated knowledge of sexology had already proven instrumental in calls by legal scholars and sexologists for decriminalization of sodomy.

43. Healey, Homosexual Desire, 221.

44. Ignatov, Otvetstvennost' za prestupleniia, 181.

45. Ibid., 182.

46. On the history of Soviet sexopathology see: Kon, Sexual Revolution, 90-102. See also: Lev Shcheglov, "Medical Sexology," in Igor S. Kon and James Riordan, eds., Sex and Russian Society, (London, 1993). On medical discourse on "sexual perversions" in the Soviet Union see: Vladimir Volodin, Kvir-istoriia Belarusi vtoroi poloviny XX veka: Popytka priblizheniia (Minsk, 2016), at www.belarusianqueerstory.noblogs.org (last accessed December 12, 2017); Nikolai V. Ivanov, Voprosy psikhoterapii funktsional'nykh seksual'nykh rasstroistv (Moscow, 1966), 4. 
For instance, Czechoslovakian sexologists' argument that homosexuality was incurable, had helped them convince the government authorities to cease all forms of legal sanctions applied to homosexual people, which eventually resulted in the decriminalization of consensual sodomy in $1961 .{ }^{47}$ The German Democratic Republic followed suit in 1968. There, consensual homosexual acts between men ceased to be a crime on the grounds that homosexuality was a medical condition and therefore should not be subject to police action. ${ }^{48}$ Finally, medical arguments framing homosexuality as a disease facilitated the decriminalization of consensual sodomy in Bulgaria in the same year. ${ }^{49}$

In contrast to the success of sexologists in the socialist bloc countries, the findings of Soviet sexological studies were not yet sufficiently influential at this time to provide a rationale for decriminalization of sodomy in the USSR. The development of Soviet sexology as a full-fledged science was significantly encumbered by long-standing negative attitudes towards sexuality and the consequent unwillingness of party officials to endorse it. In Igor Kon's words, sexopathology was "an outcast in Soviet medicine," and this status affected its research output, which in the 1960s was limited to a modest range of scholarly works. ${ }^{50}$

In 1966 Pavel Pavlovich Osipov, a legal expert from Leningrad University, defended his PhD dissertation, "Sex Crimes," which contained a section discussing the law on sodomy. ${ }^{51}$ In this section, Osipov explicitly stated that the biological nature of homosexuality warranted decriminalization of consensual homosexual acts between men. Unusual for the time, Osipov did not rely on communist ideology in his reasoning; in fact, in the introduction to his dissertation he came close to dismissing communist ideology as a reliable tool of scientific inquiry, arguing that ideology alone could not be the cornerstone of legal research. He wrote: "In light of contemporary requirements put before legal science, the study of the matters relating to the special part of Soviet Criminal Code [dealing with sex crimes], should not be confined by a dogmatic analysis of contemporary legislation." 52

Osipov's preference for an empirical rather than ideological approach was consistent with a new strategy of "rationalization" adopted by the Soviet leadership in the mid- and late 1960s. This strategy called for the revival of scientific ethos and encouraged scholars to use "scientific methods" in their

47. Jan Seidl, "Decriminalization of Homosexual Acts in Czechoslovakia in 1961," in Kārlis Vērdinš and Jānis Ozoliṇš, eds., Queer Stories of Europe (Newcastle upon Tyne, Eng., 2016), 174-95. See also: V. Sokolova, "State Approaches to Homosexuality and Nonheterosexual Lives in Czechoslovakia during State Socialism," in Hana Havelková and Libora Oates-Indruchová, eds., The Politics of Gender Culture under State Socialism: An Expropriated Voice (New York, 2014), 85-108.

48. Josie McLellan, Love in the Time of Communism:Intimacy and Sexuality in the GDR (New York, 2011), 114-18.

49. Monika Pisankaneva, "The Forbidden Fruit: Sexuality in Communist Bulgaria," E-magazine LiterNet 68, no.7:1-10 at www.liternet.bg/publish14/m_pisankyneva/forbidden.htm (last accessed December 12, 2017).

50. Kon, Sexual Revolution, 92.

51. Pavel P. Osipov, "Polovye prestupleniia: Obshchee poniatie, sotsial'naia sushchnost' i sistema sostavov" (PhD diss., 1966).

52. Ibid, 5. 
research. As Peter Solomon has pointed out, the rationale for this strategy was that it would facilitate the development of society and help the government to address immediate problems through the use of rational and credible expertise. ${ }^{53}$

The influence of this new "rational" approach extended to legal scholarship and was at the core of Osipov's arguments for decriminalization of consensual sodomy. His dissertation offered an elaborate and substantiated argument as to why the law on consensual sodomy should be abolished: "First of all, the desire to satisfy sexual need in a homosexual way may be congenital in nature, that is, conditioned by the biological peculiarities of an organism.... As a result, for people endowed with this anomaly, homosexuality is a natural means of sexual fulfillment. That is why the widespread contention that sodomy is always a result of moral depravity cannot be regarded as valid." 54

While his colleague Ignatov had tentatively suggested that criminal prosecution of men for their congenital homosexuality might be futile, Osipov further emphasized the futility of criminalization by explicitly and unequivocally asserting that it was pointless to punish people for desires that were conditioned by nature: "One may ask what goal the legislator pursued when criminalizing non-forcible homosexuality, if at issue here are the people with a biologically distorted sexual instinct? There is no doubt that with the help of criminal law, it is impossible to rectify this biological anomaly and encourage the individuals in question to satisfy their sexual need in a heterosexual way." 55

Similarly, Osipov dismissed, as far as consensual sodomy was concerned, communist morality as an adequate frame of reference: "In the Soviet legal literature there has never been an attempt to justify criminal liability for consensual sodomy and the only argument that is usually offered against it-the [resulting] individual's depravity and his violation of communist moralitycannot be regarded as sufficient." 56

An important pillar of the argument that Osipov advanced in his dissertation was that intimate relations between two consenting adults were very difficult to investigate. ${ }^{57}$ This was a new note in the debate, and it reflects a significant broader shift in the changing of public / private divide within post-Stalinist Soviet society. Osipov's emphasis on "intimacy" is additional evidence of this change. The growing body of recent scholarship on this issue has challenged the customary understanding of Soviet society as a place where private spheres were impossible. It has demonstrated that these private spheres did exist in the Soviet Union and that the expansion of the private domain was actively taking place under Brezhnev. ${ }^{58}$ As Lewis H. Siegelbaum has shown, this expansion was facilitated by the growing Soviet economy of

53. Solomon, Jr., Soviet Criminologists and Criminal Policy, 63-64.

54. Osipov, "Polovye prestupleniia," 202.

55. Ibid., 202.

56. Osipov, "Polovye prestupleniia," 203.

57. Ibid., 204-5.

58. See, for example, Lewis H. Siegelbaum, ed., Borders of Socialism: Private Spheres of Soviet Russia (New York, 2006). 
the Brezhnev era. Economic growth led to increased availability of separate apartments and individual cars, for example. ${ }^{59}$ Expansion of private spaces offered new opportunities for people to pursue their private lives-in Steven E. Harris' words, separate apartments, "introduced privacy on a mass scale," while the interiors of parked cars, according to Lewis H. Siegelbaum "might have been used for heterosexual rendezvous and associated activities." ${ }^{\circ 0}$ It was this Brezhnev-era renegotiation of private and public boundaries within Soviet society and the diminishing ability of the state to intervene in the private domains that appear to underpin Osipov's argument: "Taking into consideration the exceptionally intimate nature of actions, directed at the satisfaction of sexual desire and hampering the effective control over the behavior of the subjects involved, the legislative ban on homosexuality cannot be effective in preventing undesirable forms of sexual-desire satisfaction from arising, nor can it stimulate people to behave properly." 61

Arguments for decriminalization of consensual sodomy also came from legal experts in other Soviet republics, including Iakov Mikhailovich Iakovlev from the Tajik SSR. Like Ignatov and Osipov, Iakovlev was a legal scholar by training-he graduated from the department of Soviet law at Moscow State University in 1933. Subsequently he had taught judicial law in various universities across the Soviet Union. ${ }^{62}$ In his article, "Liability for Sodomy According to the Soviet Penal Law" (1968), he supported his argument for the decriminalization of consensual sodomy with references to the experiences of other socialist countries, such as Czechoslovakia and the German Democratic Republic, where, as we have seen, consensual sodomy had been decriminalized on medical grounds by this time..$^{63}$ Iakovlev noted that over thirty countries in the world had already abolished anti-sodomy legislation. He wrote: "Proposals in favor of the elimination of 'consensual homosexuality' between two adults have also been made in our literature. We also believe that criminal liability for homosexuality should be eliminated ..."64 Iakovlev also argued that those homosexuals who did not pose any threat to society should be referred to doctors for treatment: "Homosexuals, whose sexual perversion was due to pathological alterations of their organism, should be rendered medical help.” 65

The basis of these arguments appears to derive from Iakovlev's awareness that in the city of Gorky such "treatment” was available-he apparently

59. Lewis H. Siegelbaum, “Cars, Cars, and More Cars: The Faustian Bargain of the Brezhnev era" in Siegelbaum, Borders of Socialism, 83-103.

60. Steven E. Harris, "I Know all the Secrets of My Neighbours": The Quest For Privacy in the Era of the Separate Apartment," in Siegelbaum, Borders of Socialism, 172; Lewis H. Siegelbaum, "Cars, Cars, and More Cars," 96. Dan Healey justly suggests that the Soviet car owner's world might have been used for "homosexual trysts" as well: Dan Healey, “from Stalinist Pariahs," 114.

61. Ibid., 204.

62. Entry for Iakov Mikhailovich Iakovlev (1902-1988), Vidnye uchenye-iuristy Rossii: Vtoraia polovina XX veka (Moscow, 2006), 507.

63. Iakov Iakovlev, "Otvetstvennost' za muzhelozhstvo po sovetskomu ugolovnomu pravu" in Voprosy kriminalistiki i kriminologii (Dushanbe, 1968), 38.

64. Ibid., 45.

65. Ibid. 
learnt of this from a treatise The Issues of Psychotherapy of Functional Sexual Disorders (1966). ${ }^{66}$ This treatise was published by one of the few Soviet sexologists who specialized in treatment of "sexual perversions"-Professor Ivanov from the city of Gorky. Iakovlev replicated Ivanov's contention that an "unfavorable environment" and "incorrect upbringing" could trigger homosexual desire. ${ }^{67} \mathrm{He}$ went on to conclude that the effective struggle against deviance could be successful through pre-emptive measures and not legal repression: "The fight against homosexuality in the absence of aggravating circumstances has to be conducted not through legal repression, but through correct sex education in family and school." 68

Thus, with the slow development of Soviet expertise in sexology, which framed homosexuality as a matter of therapeutic concern, legal scholars arguing for decriminalization of sodomy could rely on sexology's findings to lend scientific credence to their arguments. That appears to be the case with Iakovlev's arguments. The writing of his article coincided with the publication of Ivanov's recent work, while previous arguments for sodomy decriminalization promoted by Ignatov and Osipov were grounded in outdated sources.

\section{The MVD's Objections to Decriminalization}

In the period from the mid- to late 1960s legal experts enthusiastically developed their arguments for decriminalization of consensual sodomy, relying on the emerging expertise of sexologists at home and acknowledging the importance of the wave of repeals of anti-sodomy laws in western and socialist countries. Yet, their arguments found no support from MVD scholars, who put communist morality before science and began to express strong opposition to the idea of decriminalizing consensual sodomy.

Before we proceed to the examination of the MVD scholars' counterarguments, we will examine the deliberations of a conference, held in 1970 in the Soviet Republic of Lithuania that was devoted to the discussion of sex crimes. ${ }^{69}$ The conference was organized by the republic's procuracy and was attended by forensic experts and criminologists, who maintained close professional ties with law-enforcement agencies. The principles spelled out by one of the speakers in the introductory paper to this conference are crucial for our understanding of what stood behind the MVD scholars' rejection of the proposal to decriminalize consensual sodomy. The introductory paper to the conference postulated:

[At the basis of socialist society] ... there is socialist morality, that is, the complex of rules and principles defining the citizen's behavior in all the spheres, including that of sexual relations. Sexual morality is one of the

66. N. V. Ivanov, Voprosy psikhoterapii funtsional'nykh seksual'nykh rasstroistv (Moscow, 1966), 128-39.

67. Iakovlev, "Otvetstvennost' za muzhelozhstvo," 42.

68. Ibid., 45.

69. Some of the conference's papers were included in a conference brochure: Fedor Arkhipov, ed., Prestuplenia protiv nravstvennosti: Materialy nauchno-prakticheskoi konferentsii (Vil'nius, 1970). 
facets of socialist moral consciousness and to deny it means to deny the necessity of moral regulation of the relations between man and woman. ... The fundamental rules of sexual morality, which determine the mode of sexual relations in the USSR, are the following: sexual relations are permissible only between the individuals of the opposite sex. ${ }^{70}$

It is difficult to say who precisely was "denying" sexual morality; yet, we have already seen that one of the proponents of decriminalization of consensual sodomy, Pavel Osipov, had indeed stated that outlawing homosexuality solely due to its ostensible infringement of communist morality was not justifiable. ${ }^{71}$ The paper's stress on the impropriety of same-sex relations in the Soviet Union and "denial" of sexual morality could represent unspoken anxieties associated with the growing voices of the proponents for decriminalization of consensual sodomy among some legal scholars. Yet, more evidence is needed to establish whether this was the case.

The introductory statement of the 1970 conference gives us a better understanding of what motives lay beneath the MVD scholars' opposition to the decriminalization of consensual sodomy. It also suggests that by 1970, the communist concepts of sex and love, introduced under Khrushchev, had evolved and become more complicated. The Khrushchev-era discourse did not clearly delineate the limits of admissible sexual behavior-sex educators expressed a variety of opinions as to what the demands of sexual morality were. These demands, as Deborah Field tells us, generally revolved around the idea that one had to practice "sex within marriage, accompanied by love, preferably for the purposes of procreation." ${ }^{72}$ Homosexuality was mentioned only rarely and Soviet moralists never explained its relationship to communist morality ${ }^{73}$ However, the conference paper of 1970 clearly defined what sexual practices were permissible in the USSR. It seems plausible that once these rules were clearly defined, they became a frame of reference for MVD scholars, which would require them to oppose the arguments of proponents for sodomy decriminalization more strongly.

One of the most outspoken opponents of decriminalization of consensual sodomy was a scholar from the MVD Higher School-Boris Vasil'evich Daniel'bek, who expressed his views in a textbook, Sexual Perversions and Criminal Liability, in $1972 .{ }^{74}$ The textbook was addressed to the students of the MVD schools and "practitioners of the law-enforcement agencies." In one of his chapters on the law of sodomy Daniel'bek strongly criticized the

70. Arkhipov, Prestuplenia protiv nravstvennosti, 10.

71. Osipov, "Polovye prestupleniia," 202-3.

72. Field, "Communist Morality and Meanings of Private Life," 123.

73. Iosif Gyne, Iunosha prevrashchaetsia v muzhchinu (Moscow, 1960), 36. See also: Serafim A. Artem'ev, Vasilii D. Kochetkov, and German G. Shtan'ko, Gigiena polovoi zhizni (Moscow, 1964), 20.

74. Boris V. Daniel'bek, Polovye izvrashcheniia i ugolovnaia otvetstvennost' (Volgograd, 1972). This textbook appears to be based on Daniel'bek's dissertation "Criminal and Legal Fight with Sex Crimes" [Ugolovno-pravovaia bor' ba s polovymi prestupleniami], which he defended in 1970 in the MVD Higher School. I was able to find only the abstract of his dissertation [avtoreferat dissertatsii], which is available in the Russian National Library. 
arguments for decriminalization advanced by Osipov and Iakovlev and concluded that their view on the subject was "unacceptable."75

Exploring each argument promoted by Osipov and Iakovlev, Daniel'bek explained why they were not convincing. Reminding the reader of Osipov's contention that violation of communist morality was not a sufficient reason to criminalize consensual sodomy, Daniel'bek simply wrote: "Negative personality traits, if they infringe on the principles of socialist morality, may be viewed as criminal." ${ }^{76}$

Osipov's second argument that consensual sodomy should be decriminalized due to the "intimate nature" of homosexual behavior and the difficulty of dealing with such crimes was also dismissed by Daniel' bek: "The intimate nature of homosexual acts, conducted on a consensual basis, indeed hampers the prosecution of people involved in it; however, it does not mean that the law against consensual sodomy should be eliminated."77

Finally, Daniel'bek disagreed with Osipov's third contention, which asserted that the anti-sodomy law failed to encourage homosexuals to practice heterosexual sex: "... criminal prosecution of homosexuality is not the most effective means of its prevention. Indeed, in order to curb this immoral inclination a combination of societal and medical intervention is needed in the first place, however, one cannot dismiss the educational importance of criminal prosecution." 78

Osipov was not the only target of Daniel' bek's attack. Iakovlev from the Tajik University also received his share of criticism. As discussed above, Iakovlev had stated that proper sexual education was a better strategy than criminal punishment and that crimes of consensual sodomy were very hard to investigate. Daniel'bek completely disagreed with such claims: "The correct sexual upbringing is indeed an important means of sodomy prevention, including prevention of any other crime in the sphere of sexual relations. However, no matter how tempting it is to base the decriminalization of sex crimes on this assumption, such a proposition is ill-timed."79

Then he continued: "The contention that criminal cases involving sodomy are rarely encountered is rather controversial. ... Criminal punishment plays an important role in homosexuality prevention and constitutes a restraining factor on those inclined to such vice. Summing up, we express our strong conviction that the criminalization of consensual sodomy in our legislation is justified and there are no reasons to alter the existing legislation." ${ }^{\circ 0}$

Underlying Daniel'bek's arguments was the same long-standing conviction that homosexuality was a vice that had to be controlled by law-enforcement agencies: "Homosexuality in the absolute majority of cases is a result of negative conditions, which formed a personality. ... These very conditions lead some people to such degrees of perversion, when normal satiation of

75. Daniel' bek, Polovye izvrashcheniia, 87.

76. Ibid., 89.

77. Ibid., 90.

78. Ibid.

79. Ibid., 91.

80. Ibid., 92. 
sexual desire does not give them normal satisfaction anymore and they resort to perversions in order to experience extra thrills [ostrye oshchushchenia]."81

Daniel' bek's arguments demonstrate that his views on consensual sodomy had not been altered by medical knowledge on sexual perversions, which the proponents of consensual sodomy decriminalization had readily embraced. Nor was he willing to take into account the fact that by 1970 consensual homosexual acts had been decriminalized in many countries, or to entertain the possibility that the Soviet Union might follow suit. Instead, he preferred to categorize homosexuality as a crime against morality and consider it a threat to the moral foundations of Soviet society. The defensive nature of his arguments and his staunch support of communist morality apparently stemmed from the functions that lay at the heart of the Soviet militia's activities. As Louise I. Shelley has explained, the Soviet militia played an important role in protecting the security of the state and enforcing political conformity, clearly communicating the limits of acceptable political behavior in Soviet society. It not only controlled crime, but also ensured citizens' compliance with official state ideology. ${ }^{82}$

The MVD scholars' opposition to decriminalization did not prevent legal experts from Leningrad University from expressing contrary views on the subject. Nor did it discourage them from articulating their views in the manual, A Course in Soviet Criminal Law, published in 1973, which included a discussion of the consensual sodomy law and which was intended for a wider audience. ${ }^{83}$ The anonymous author of the entry on the consensual sodomy law expressed "serious doubts regarding the expediency of keeping criminal liability for consensual sodomy." ${ }^{4}$ The entry listed three arguments, summarizing the contentions previously expressed by Osipov and Iakovlev (it is possible that the author of the entry was Osipov himself) in favor of reconsideration of the anti-sodomy statute. In addition to existing arguments highlighting the "biological" nature of homosexuality and the impossibility of controlling it due to its intimate nature, the manual presented a new argument, which invoked decriminalization of consensual homosexual acts outside of the Soviet Union, implicitly suggesting that since such developments occurred in socialist countries, then the Soviet Union should also go down the same path:

Thirdly, the development of criminal legislation over recent years testifies to the gradual departure from criminalization of consensual sodomy, not only in capitalist countries (England and West Germany), but also in socialist countries (East Germany, Hungary, Czechoslovakia, Bulgaria, Poland). The aforementioned arguments testify to the expediency of the exclusion from the existing legislation of the article criminalizing consensual sodomy. ${ }^{85}$

81. Ibid., 87.

82. Louise I. Shelley, Policing Soviet Society: The Evolution of State Control (London, 1996), 178.

83. Nikolai A. Beliaev and Mikhail D. Shargorodskii, eds., Kurs sovetskogo ugolovnogo prava: Chast' osobennaia. Tom tretii (Leningrad, 1973).

84. Ibid., 646.

85. Ibid., 647. 
It is interesting that although pro-decriminalization scholars were certainly familiar with the monographs produced within the MVD Higher School, they never openly found fault with the MVD scholars' arguments regarding the sodomy law. Perhaps, they were aware of the potential disadvantages to their careers and other undesirable consequences, which persistent discussion of such a taboo topic might entail, especially in a country where homosexuality was condemned by society and penalized by law. Nevertheless, legal scholars continued to promote their views.

In 1974, A. N. Ignatov advanced a more explicit and elaborate argument for decriminalization of consensual sodomy in his doctoral dissertation, "Problems of Criminal Liability for Sex Crimes in the Soviet Criminal Law."\$6 Unlike his previous treatise, Liability for Crimes against Morality (1966), whose arguments for decriminalizing sodomy relied on Russian books on forensic medicine and on medical literature of the pre-revolutionary period, Ignatov's doctoral dissertation saw his contentions firmly grounded in the expertise of contemporary Soviet sexology.

In the period from 1970 to 1974, Soviet sexology yielded a number of works that encompassed a wider range of topics, including a more elaborate examination of "sexual perversions," and methods for treating homosexuality. ${ }^{87}$ In early 1970, the first sexological center attached to the city health department of Leningrad began to operate; in 1973, an All-Union scientific method center started coordinating the work of sexologists across the country. ${ }^{88}$ Unlike American psychiatrists, who excluded homosexuality from the list of mental illnesses in 1973, Soviet doctors demonstrated their support for the idea that homosexuality was a pathological condition. ${ }^{89}$ Yet, even such an outdated perception of homosexuality offered a justification for the elimination of sodomy from the Soviet legal code, to which Ignatov and other legal scholars could resort. Drawing on fresh evidence, Ignatov advanced his argument that homosexuality was an inherent disposition and should be of therapeutic, rather than police concern:

At present, we may consider it to be an established fact that a certain number of people suffer from congenital perversion of sexual desire.... As it stands, people with psychological deviations are most predisposed to homosexuality. Therefore, criminalization of homosexuality is not just a

86. Aleksei N. Ignatov, "Problemy ugolovnoi otvetstvennosti za prestupleniia v oblasti polovykh otnoshenii v sovetskom ugolovnom prave" (Avtoreferat dissertatsii na soiskanie uchenoi stepeni doktora iuridicheskikh nauk, Moscow, 1974). Unfortunately, I was able to find only the abstract of the dissertation.

87. Pavel B. Posvianskii, "Vvedenie v sovremennoe uchenie o seksual'nykh perverziiakh" in Problemy sovremennoi seksopatologii: Sbornik trudov (Moscow, 1972), 79-100; Ian G. Goland, "O stupenchatom postroenii psikhoterapii pri muzhskom gomoseksualizme" in Problemy sovremennoi seksopatologii (Moscow, 1972), 473-86.

88. On the history of Soviet sexopathology see: Kon, Sexual Revolution, 90-102; Lev Shcheglov, "Medical Sexology,” 152-64.

89. On the struggle for eliminating homosexuality as an illness from Diagnostic and Statistical Manual of the American Psychiatric Association see Ronald Bayer, Homosexuality and American Psychiatry: The Politics of Diagnosis (New York, 1981). On the argument of Soviet sexologists that homosexuality was a medical problem see: Posvianskii, "Vvedenie v sovremennoe uchenie," 88-91. 
matter of law. It goes without saying that such perversion is of a pathological nature and legal sanctions are not only useless, but unjust. The fear of criminal punishment prevents homosexuals from resorting to medical help. In the medical and legal literature it has been stated multiple times that consensual homosexual liaisons between adults pose neither societal danger nor damage the state. . . . With all this in mind, the dissertation proposes to exclude the article criminalizing consensual sodomy from Soviet legislation. This opinion also gained support in Soviet legal scholarship (P.P. Osipov, I. M. Iakovlev). ${ }^{90}$

These arguments did not, however, affect the perception of homosexuality by experts affiliated with the MVD and law enforcement agencies, who continued to maintain their opposition to reform. For instance, a 1975 manual for law-enforcement agencies, Sex Crimes: Criminals and Victims, by the MVD scholar from the Kiev MVD School, Iurii Valerianovich Aleksandrov, contained a lengthy nine-page entry on the crime of sodomy, eloquently describing why homosexuality was dangerous: "Sodomy is not an illness. It is ... determined by social factors of negative personality formation. ... Apart from moral degeneration and degradation of the individuals involved in such abnormal sexual liaisons and their breakaway from social activity ... sodomy infringes on the health of homosexuals, facilitates the widespread dissemination of venereal diseases ..."91

Most importantly, Aleksandrov argued that the existing law criminalizing consensual sodomy in Ukrainian SSR should be revisited with a view to introducing stricter penalties: "Our experience has proven that milder penalties (up to 1 year of imprisonment) in the majority of cases do not have the desired effect on this cohort [homosexuals]. The deterrent value of such a measure is also insignificant." Following that contention, the author proposed that the penalty for consensual sodomy in the Ukrainian SSR be elevated to five years of imprisonment. ${ }^{92}$

Aleksandrov also restated the commitment of Soviet criminal law to penalize consensual sodomy: "It is known that the Soviet penal law insists on penalizing consensual sodomy. Given the high degree of social danger posed by this crime one cannot but agree with such a stance." 93 Aleksandrov was aware of the view promoted by Osipov, since he noted that Soviet legal schools had suggested decriminalizing consensual sodomy, referring to Osipov's dissertation of $1966 . .^{94}$

Aleksandrov expressed his dissatisfaction at the absence of penalties for other forms of same-sex relationships apart from sodomy, echoing the long-standing inclination of law-enforcement agencies to criminalize female same-sex relations: "Sodomy is only one of different displays of homosexual relations. Other forms of these displays should be considered no less immoral,

90. Ignatov, Problemy ugolovnoi otvetstvennosti, 28-29.

91. Iurii V. Aleksandrov, Polovye prestupleniia: Prestupniki i poterpevshie (Kiev, 1975), 38.

92. Aleksandrov, Polovye prestupleniia, 87-88. In Ukrainian SSR, consensual sodomy was punishable with up to one-year imprisonment and up to three years exile.

93. Ibid., 87.

94. Ibid., 88. 
cynical and corrupt, and therefore, carrying no less societal danger than sodomy. Yet, these forms of sexual relations are not penalized."95

Aleksandrov's manual, Sex Crimes: Criminals and Victims, seems to be the last public source to discuss the value of the law on sodomy in a series of manuals and dissertations produced in the period from 1965 to 1975 by Soviet legal and MVD scholars. Although this discussion then disappeared from public sources, legal scholars made some offstage attempts to push the Interior Ministry for change. Igor Kon tells us that in 1979 A. N. Ignatov sent a memorandum to the MVD, listing arguments for decriminalization of consensual sodomy. He never received a response. ${ }^{96}$ The meaning of this silence was plain and obvious: MVD officials were not going to introduce any changes to the existing legislation.

New evidence suggests that the attitudes of some influential members of the Soviet establishment towards perceived deviant sexual behavior remained extremely conservative. For instance, on June 27, 1977, the Supreme Court of the Latvian SSR advocated for stronger penalties for sex crimes, including for "perverted" sexual practices such as oral and anal sex. The Supreme Court proposed introducing a new article to the Latvian SSR Criminal Code under the title "Satisfaction of sexual desire in perverse forms." ${ }^{\text {"T }}$ This article would criminalize coercive oral and anal sex as part of rape, accompanying sodomy. The proponents of the new law argued that "forcible satisfaction of sexual desire in perverse form presents no less danger than rape or sodomy and attests for utmost cynicism and depravity of the criminal ..."98 The emphasis on the "perverted nature" of oral and anal sex, expressed by describing these practices as "disgusting," "cynical," and simply as "sexual perversions," as well as attempts to distinguish "natural" forcible sex from "perverted" forcible sex, demonstrate the extent to which some Soviet authorities were guided by their prudish attitudes and their own perceptions of "normal sexuality." 99 Clearly, as long as these perceptions held sway, the decriminalization of consensual sodomy was apparently out of the question. Yet, despite extensive discussion about the proposed law, the draft was eventually rejected on the grounds that it needed further consideration. ${ }^{100}$

A decade later, when Gorbachev's perestroika and glasnost significantly relaxed censorship, the discussion of sex and related topics became possible in the pages of the Soviet press. In December 1989, the monthly periodical Molodoi Kommunist featured a lengthy article on the problem of homosexuality in the Soviet Union. In this article, A. N. Ignatov briefly summarized the current state of discussion on the law on sodomy between its proponents and opponents:

95. Ibid., 88.

96. Igor' S. Kon, Klubnichka na berezke: Seksual'naia kul'tura v Rossii (Moscow, 1997), 359.

97. The State Archive of Latvia, f. 938, op. 6, delo 1188, 1.10 (Zakliuchenie na proekt Ukaza PVS LSSR “O dopolnenii Ugolovnogo kodeksa LSSR stat'ei 121[1]).”

98. The State Archive of Latvia, f. 938, op. 6, delo 1188, 1.11. Zakliuchenie na proekt Ukaza PVS LSSR “O dopolnenii Ugolovnogo kodeksa LSSR stat'ëi 121(1)”

99. Ibid., 20-24.

100. Ibid., 1. 
The majority of authors who write on this topic come to the conclusion that criminal liability for homosexuality is not expedient. Why? First, if it is pathology, then it cannot be punished. Second, there is no danger for society here. In fact, all the main arguments of the proponents of criminal liability for homosexuality are refuted. Which ones exactly? Well, that homosexuality will lead to the decreased masculinity of the nation. Yet, the example of Sparta demonstrates the contrary. Another alleged consequence of homosexuality is that it will decrease birth rates. The statistics do not confirm this conclusion. Then, they say that it leads to the degradation of a person. However, we know many great homosexuals-Tchaikovskii, Leonardo da Vinci, and so on, and their creative work refutes the previous statement. ${ }^{101}$

According to Ignatov the opponents of decriminalization of sodomy were also convinced that if there was no law in place, then homosexuality would thrive. ${ }^{102}$ MVD scholars had expressed such views as early as 1972, and as Ignatov showed they persisted well into the 1980s:

There is a lay perception that if we abolish article 121 of the Criminal Code then everyone will start to engage in homosexuality! Nonsense! A person, who has no propensity for it cannot be influenced by the absence or existence of criminal liability. Criminal liability does not influence the person who has such propensity. Criminal liability plays little role here-it neither reduces nor eliminates homosexuality, because sexual needs, whatever you may say, are some of the strongest ... ${ }^{103}$

Most importantly, Ignatov's comment presented an illuminating account of the reasons underlying the reluctance of Soviet officials to listen to the arguments of legal scholars for the repeal of the sodomy law. Ignatov explained that the ultimate decision to abolish the sodomy law was often left to individual Soviet bureaucrats, who had the final word on everything and often had the power to dismiss the most well-conceived and substantiated draft law on the grounds of personal distaste without any explanation or further comment: "In former times, a person, who was not a legal expert, but who held a senior position, could say something like this at the last moment: 'And what is this? Let's cross this out! Or, conversely, let's add something.' As a result, a well-thought-out and well-substantiated proposed law changed abruptly."104

MVD officials were also willing to express their opinion about the problem during perestroika. For instance, in 1990 the newspaper Argumenty i Fakty published an opinion of V. Kachanov, an official from the Moscow Criminal Investigations Department, who argued that the sodomy law was a "restraining factor" for homosexuals "responsible for the dissemination of AIDS."105

The question of what discussions took place behind closed doors in the immediate run-up to sodomy decriminalization in April 1993 by El'tsin

101. Aleksei Novikov, “Sindrom 'Trekh obez'ianok," Molodoi Kommunist no. 12 (December 1988): 71.

102. Daniel'bek, Polovye izvrashcheniia, 89.

103. Novikov, "Sindrom "Trekh obez'ianok," 71.

104. Ibid.

105. A. Petrov, letter to the editor, Argumenty i Fakty no. 9 (1990): 7. 
requires further examination. Yet it is evident that these discussions continued to be defined by the positions that had emerged in the previous decades.

Although it may appear extraordinary, the first attempts to decriminalize sodomy in the Soviet Union were undertaken in the late 1950s, when new criminal codes for Soviet republics were drafted. The different drafts varied considerably. While there was discussion in the RSFSR regarding the possibility of revising the Stalin-era Criminal Code so as to decriminalize sodomy, in the Soviet republic of Latvia the legislators instead considered introducing criminal penalties for female same-sex relations. In any event, ultimately neither of these proposals was implemented.

The archival documents, which reflect these unusual discussions, demonstrate that as early as the late 1950s some Soviet legal academics advocated for the abolition of the anti-sodomy law, while law-enforcement agencies wanted not only to leave it in place, but to strengthen it. This divide between academic and law-enforcement opinions on the anti-sodomy law persisted into the Brezhnev era, taking the form of a fully-fledged debate that was reflected in the manuals and dissertations produced by Soviet legal scholars and criminologists, even if it did not find its way into the Soviet mainstream public domain.

As the discussion unfolded, the positions of the participants in the debate became more differentiated and obvious. On the one side stood MVD officials, who argued for the retention of the anti-sodomy statute; on the other, the legal scholars, who argued for its abolition. Whereas legal scholars were refining their arguments in favor of sodomy decriminalization over time, making adroit use of the findings of foreign and domestic sexology research as well as taking into account changes to the relevant legislation abroad, the arguments of MVD scholars remained largely unchanged and unaffected by these developments. Throughout this period, MVD scholars consistently relied on "communist morality" to argue that homosexuality was dangerous and detrimental to existing moral norms and criticized legal scholars for their propositions to eliminate the law on sodomy.

Intriguingly, discussion of sodomy law in these sources came to a halt by 1975, and yet it appeared that the issue of decriminalization never stopped weighing on the minds of those how advocated for it. For example, in a memorandum, written to the Interior Ministry in 1979, A. N. Ignatov argued for decriminalization of sodomy once again. He never received a reply. ${ }^{106}$ As he later explained, personal distaste for homosexuality, particularly among many Soviet officials, never predisposed them favorably towards decriminalizing sodomy. ${ }^{107}$

The emerging freedom of the press in the Gorbachev era allowed for hitherto discreet discussion between legal academics and MVD officials to appear widely on the pages of Soviet newspapers. This stage of the debate on the sodomy law was cut short by the deadly AIDS epidemic, which hit the Soviet Union in the late 1980s. The rise of AIDS gave law-enforcement agencies

106. Kon, Klubnichka na berezke, 359.

107. Novikov, "Sindrom 'Trekh obez' ianok," 71. 
renewed leverage. They now argued that retention of the anti-sodomy law was crucial for preventing the disease from spreading, as homosexuals were perceived as the main carriers of AIDS. ${ }^{108}$ Yet, A. N. Ignatov did not lose hope; instead, he publicly pledged to continue to advocate for the abolition of the law, believing that since Gorbachev was a legal scholar by education, he would be more inclined to listen to the legal experts: "Along with other legal experts I will continue to struggle for the abolition of this law. We are confronting the prejudice of the majority of the population and the opinion of influential officials ... we count on Gorbachev. He is a legal expert ...."109

Ultimately, however, it was Boris El'tsin not Gorbachev, who removed the notorious law from the statute books in April 1993. While El'tsin's personal desire to join the Council of Europe certainly underpinned his decision to repeal the sodomy law, it is also important to recognize that this was not something entirely new: a bottom-up movement for decriminalization of sodomy among Soviet leading legal experts and their scholarly arguments discussed in this article, also appeared to be crucial. We still have much to learn about the neglected history of these debates.

108. Argumenty i Fakty no. 9 (1990).

109. Valerii Rodikov, “Golubye eli . ..,” Literaturnaia Rossiia no.12 (March 1990): 24. 